\title{
Flotation and Sorptive-Flotation Methods for Removal of Lead Ions from Wastewater Using SDS as Surfactant and Barley Husk as Biosorbent
}

\author{
Ahmed A. Mohammed, Shahlaa E. Ebrahim, and Abeer I. Alwared \\ Environmental Engineering Department, College of Engineering, Baghdad University, Baghdad, Iraq \\ Correspondence should be addressed to Abeer I. Alwared; abeerwared@yahoo.com
}

Received 23 May 2013; Revised 17 July 2013; Accepted 25 July 2013

Academic Editor: José Morillo

Copyright (C) 2013 Ahmed A. Mohammed et al. This is an open access article distributed under the Creative Commons Attribution License, which permits unrestricted use, distribution, and reproduction in any medium, provided the original work is properly cited.

\begin{abstract}
The removal of lead ions from simulated wastewater was investigated using flotation and sorptive-flotation methods. This was achieved by using sodium dodecyl sulfate (SDS) as surfactant and barley husk as biosorbent. Experiments were carried out to study the effect of various parameters such as $\mathrm{pH}(3,5$, and 8$)$, initial lead ions concentration $(25,50$, and 100$) \mathrm{mg} / \mathrm{L}$, flow rates $(500$, 1000 , and $1500 \mathrm{~mL} / \mathrm{min}$ ), and SDS concentration $(25,50$, and 100$) \mathrm{mg} / \mathrm{L}$. The results show that the removal efficiency was enhanced by about $10 \%$ when using sorptive-flotation compared with flotation only at the same conditions. Langmuir isotherm model with $q_{m}=12.7$ and high determination coefficient equal to 0.988 was found to give the best fit to the experimental data compared to Freundlich isotherm model with $k=3.49$ and correlation coefficient equal to 0.94 . Pseudo-first-order and pseudo-second-order kinetic models were studied and the results show that the adsorption data correlated with pseudo-first-order kinetic model with $k_{1}$ equal to 0.122 , and this is an indicator to the reversible interaction with equilibrium being established between liquid and solid waste.
\end{abstract}

\section{Introduction}

Lead is a natural compound that exists in elemental, inorganic, and organic forms. Lead is present in trace amounts in all soils, water, and foods. It is soft, malleable, blue-gray in color and is highly resistant to corrosion. These properties, along with the poor ability of lead to conduct heat and electricity, probably contributed to its use in mining, smelting, refining, battery manufacturing, soldering, electrical wiring, home demolition and construction, painting, ceramic glazing, and the making of stained glass [1].

The heavy metal lead is among the most common pollutants found in industrial effluents. Even at low concentration, this metal can be toxic to organisms, including humans, as it is extremely toxic and can damage the nervous system, kidneys, and reproductive system, particularly in children. Lead is known to have a toxic effect on the neuronal system and the function of the brain cells $[2,3]$. The US Environmental Protection Agency (EPA) requires lead not to exceed $0.015 \mathrm{mg} / \mathrm{L}$ in drinking water [4]. Therefore, cost-effective treatment technologies are needed to meet these requirements of recovery and/or removal of metal ions.

Biosorption of heavy metals from aqueous solutions is a relatively new technology for the treatment of industrial wastewater. The major advantages of biosorption technology are its effectiveness in reducing the concentration of heavy metal ions to very low levels and the use of inexpensive biosorbent materials [5]. Biosorbents are prepared from the naturally abundant and/or waste biomass which has the ability to sequester heavy metals: these biosorbents are bacteria [6] and algae [7].

A search for a low-cost and easily available adsorbent has led to the investigation of materials of agricultural and biological origin as potential metal sorbents [8]. Many materials which are cheap and readily available sources such as coal, coke, peat, wood, rice husk, or barley husk may be successfully employed for the removal of lead and other toxic heavy metals from aqueous solutions. The utilization of agricultural waste materials is increasingly becoming an important concern because these wastes represent unused 
resources and, in many cases, present serious disposal problems [9].

Yadla et al. in 2012 [10] used fly ash as low cost and abundantly available adsorbent and they concluded that the percentage removal of lead from the aqueous solution amplifies with decrease in size of the adsorbent particles and is augmented with increase of the adsorbent. Percentage removal of lead from the aqueous solution is increased significantly with the decrease in acidity, and the increase in percentage adsorption is maximum between $\mathrm{pH}$ values 4 and 6 and decreased at $\mathrm{pH}$ above 7.

Gupta et al. in 2010 [11] used the biosorbents (untreated and acid-treated algae) for removal of $\mathrm{Ni}$ (II) ions and they concluded that the proposed adsorbent is effective in terms of its performance compared with other biosorbents.

Flotation as a separation process has recently received a considerable interest owing to its simplicity, rapidity, economy, good separation yields (recovery $>95 \%$ for small impurity agent concentrations (10.6-10.2 mol/L), a large possibility of application for species having different nature and structure, flexibility and friability of equipment and processing for recovery purpose and production of more concentrated sludge, occupying smaller volumes $[12,13]$. It is believed that this process will soon be incorporated as a clean technology to treat water and wastewater [14]. For the aforementioned reasons, a combination of adsorption and flotation into a unified operation termed sportive-flotation could be considered as a vital process.

Stoica et al. in 2012 [15] used biosorption-flotation experiments in order to recover loaded mycelial penicillium waste from aqueous solution; the mycelial penicillium was loaded with $\mathrm{Cd}(\mathrm{II})$ and $\mathrm{Pb}(\mathrm{II})$ resulted and then concluded that the efficiency being dependent on process optimal parameters.

The aim of the present research is to investigate the lead ions removal by floatation and sorptive-floatation methods in batch process using barley husk as a biosorbent. The optimum weight of the barley husk was calculated through the equilibrium isotherm model. The effect of $\mathrm{pH}$, different lead ions concentrations, flow rate, and SDS concentration on the performance of floatation process was conducted.

\section{Mathematical Models}

2.1. Kinetics Models. There are various kinetic models used for evaluating the rate constant for floatation and biosorption of $\mathrm{Pb}(\mathrm{II})$ onto barley husk. The pseudo-first-order reaction was widely used for the adsorption of liquid/solid system. The linear form is generally expressed as follows [16]:

$$
\ln \left(q_{e}-q_{t}\right)=\ln q_{e}-k_{l} t
$$

where $q_{e}(\mathrm{mg} / \mathrm{g})$ and $q_{t}(\mathrm{mg} / \mathrm{g})$ are the adsorption amount at equilibrium and at time $t(\mathrm{~min})$, respectively. $k_{l}\left(\mathrm{~min}^{-1}\right)$ is the rate constant. While the pseudo-second order model is based on the assumption that the adsorption follows second order is chemisorptions. The linear form can be written as follows [17]:

$$
\frac{1}{q_{t}}=\frac{1}{k_{2} q_{e}^{2}} \frac{1}{t}+\frac{1}{q_{e}}
$$

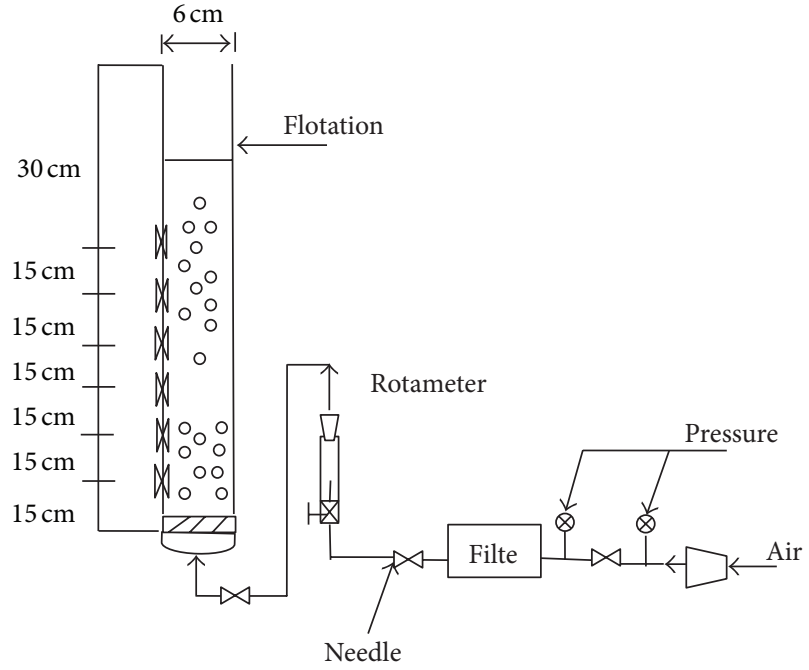

FIGURE 1: Schematic diagram of the experimental setup.

where $k_{2}(\mathrm{~g} / \mathrm{mg} \cdot \mathrm{min})$ is the rate constant of adsorption, $q_{e}$ is the amount of metal adsorbed at equilibrium $(\mathrm{mg} / \mathrm{g})$, and $q_{t}$ is the amount of metal adsorbed at time $t(\mathrm{mg} / \mathrm{g})$.

\section{Materials and Methods}

Two types of experiments were carried out in this study: floatation and sorptive-floatation.

\subsection{Materials}

Flotation. Sodium dodecyl sulfate (SDS, 99\%) from Fisher Scientific was used as anionic collector; it is a white powder material with a chemical structure of $\mathrm{C}_{12} \mathrm{H}_{25} \mathrm{OSO}_{3} \mathrm{Na}$, M.wt $=$ $288.38 \mathrm{~g} / \mathrm{mole}$. Ethanol $\left(\mathrm{C}_{2} \mathrm{H}_{5} \mathrm{OH}\right)$ from Lancaster Synthesis was used as frother: $\mathrm{Pb}\left(\mathrm{NO}_{3}\right)_{2}$ purity $=99.5 \%$ wt, M.wt $=$ $207.2 \mathrm{~g} / \mathrm{mole}$.

Sorptive-Flotation. Barley husk was used as biosorbent.

Reagents. Hydraulic acid (HCL) and caustic soda $(\mathrm{NaOH})$ were used for $\mathrm{pH}$ adjustments.

3.2. Methods. The foam flotation tests were carried out in a bubble column (acrylic) of $6 \mathrm{~cm}$ inside diameter and $120 \mathrm{~cm}$ in height. Figure 1 shows a schematic diagram for the experimental apparatus. Air was supplied by the compressor (compressed at 1 bar up 7 bars) to the column through a precalibrated rotameter. Air that entered the column was dispersed as bubbles into liquid. Air distributor plate that has 25 holes with $0.05 \mathrm{~cm}$ diameter was used. The holes are arranged in the equilateral triangular pitch through the whole area which are located inside the column. The column was operated at batch mode as far as the liquid phase and continuous flow with respect to air. The samples were drawn through tap from the column. Feed inter with different metal concentration (25 up to $100 \mathrm{ppm}$ ) was poured gently at the top of the column. At the same time, the column was pressurized so as not to weep the liquid through the holes. 
Synthetic polluted water samples were prepared by dissolving $\mathrm{Pb}\left(\mathrm{NO}_{3}\right)_{2}$ in distilled water. Surfactants and ethanol were added to the synthetic polluted water. $\mathrm{pH}$ was adjusted to a desired value using $\mathrm{HCL}$ or $\mathrm{NaOH}$.

The barley husk was sieved on 28/32 mesh with geometric mean diameter of $0.5 \mathrm{~mm}$. The required sieve fraction was removed and washed to remove fines from the crushed husk. The husk was placed in a clean baker filled with distilled water. Then it was stirred with a glass rod and allowed to settle for 5 minutes. The supernatant was poured off and new distilled water was added. This process was repeated twice until the supernatant was clear. The wet husk was dried in an oven at $100^{\circ} \mathrm{C}$ for 24 hours, after which the husk was kept in a desiccator for use.

For the determination of adsorption isotherms, $250 \mathrm{ml}$ flasks were filled with known concentration of solute and a known weight of barley husk. The flasks were placed on a shaker and were agitated continuously for $6 \mathrm{~h}$ at $25 \pm 3^{\circ} \mathrm{C}$. The concentration of lead(II) in the solution was determined using atomic absorption spectrophotometer device. The adsorbed amount is calculated by the following equation:

$$
q_{e}=\frac{V\left(C_{o}-C\right)}{W},
$$

where $q_{e}$ is the internal concentration of solute per unit weight of activated carbon, $V$ is the volume of the container, $W$ is the weight of the activated carbon, and $C_{o}$ and $C$ are the initial and final solute concentrations. The amount of barley husk was calculated for the final equilibrium-related concentration of $C_{e} / C_{o}=0.05$. Foam samples were taken at preset time intervals as $5,10,15,20,25$, and 30 minutes. A port $0.45 \mathrm{~m}$ above the base was used for periodic sampling. About $3 \mathrm{~mL}$ of solution was drained from the port before withdrawing each sample; samples were withdrawn slowly to minimize entrainment of air bubbles. Between experiments, the column was cleaned using HCL and then rinsed three times with double-distilled water.

\section{Results and Discussion}

4.1. Equilibrium Isotherm Results. The adsorption isotherms display a nonlinear dependence on the equilibrium concentration. The adsorption data for the system was fitted with two models. The determination coefficients are shown in Table 1. This table indicates that the Langmuir model provides the best fit as judged by its correlation coefficient. Figure 2 represents the adsorption isotherm for lead ions onto barely husk.

4.2. Effect of $p H$. Generally, adsorption and flotation are sensitive to variations in the $\mathrm{pH}$ value of the medium, and knowing how the $\mathrm{pH}$ affects each system was a prerequisite to study employing these methods. $\mathrm{Pb}(\mathrm{II})$ is the dominant species below $\mathrm{pH}$ 5.5. Between $\mathrm{pH} 6$ and 10, $\mathrm{Pb}$ (II) undergoes hydrolysis to $\mathrm{Pb}(\mathrm{OH})_{2}$. Above $\mathrm{pH} 9$, solid lead hydroxide $\mathrm{Pb}(\mathrm{OH})_{2}$ is thermodynamically the most stable phase, while $\mathrm{Pb}(\mathrm{OH})_{3}$ is predominant at $\mathrm{pH}$ above 11 [1].
TABLE 1: Parameters of isotherm for $\mathrm{Pb}(\mathrm{II})$ and correlation coefficient for two models.

\begin{tabular}{lcc}
\hline Model & Parameters & $\mathrm{Pb}(\mathrm{II})$ \\
\hline Langmuir [18] & $q_{m}$ & 12.7 \\
$q_{e}=\frac{q_{m} b C_{e}}{\left(1+b C_{e}\right)}$ & $b, 1 / \mathrm{mg}$ & 0.15 \\
\hline Freundlich [19] & Correlation coefficient & 0.988 \\
$q_{e}=K_{F} C_{e}^{1 / n}$ & $K$ & 3.49 \\
& $n$ & 2.99 \\
\hline
\end{tabular}

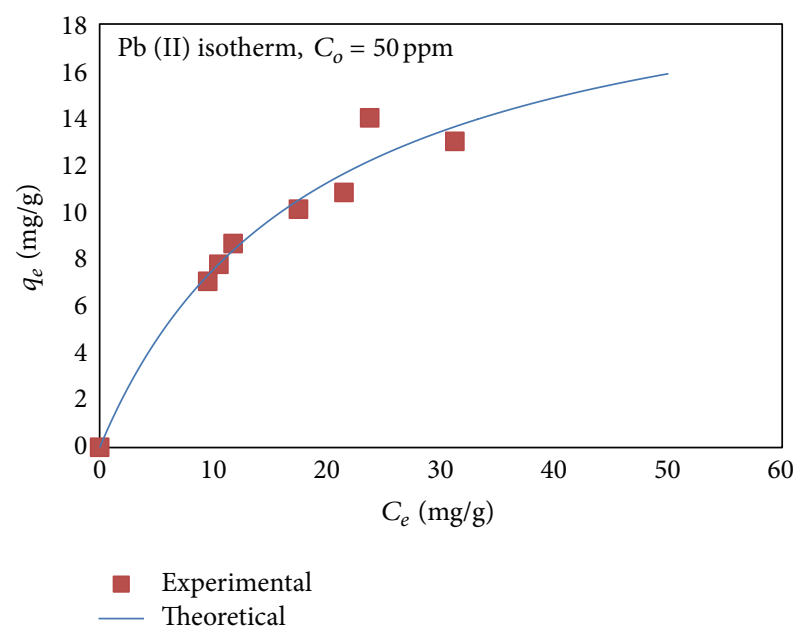

FIgURE 2: Adsorption isotherm for $\mathrm{Pb}$ (II) onto barley husks biosorbent.

The influence of $\mathrm{pH}$ on the combined process (sorption and flotation) for the removal of $\mathrm{Pb}$ (II) was investigated in the absence and presence of barley husks; Figure 3 shows that the best removal was at $\mathrm{pH}=8$ for floatation and for sorptivefloatation.

Inspection of the figure indicated that the use of barley husks as a sorbent increases the removal of $\mathrm{Pb}(\mathrm{II})$ as $\mathrm{pH}$ increased; a maximum removal efficiency value attained was $82 \%$ when using sorptive-flotation, while for flotation a maximum value was $78.4 \%$.

When the $\mathrm{pH}$ value increases, more metal binding occurs. $\mathrm{pH}$ variation can modify the speciation and the availability of the metallic elements in solution particularly at these properties related to hydrolytic reduction Kefala et al. [20].

The chemical state of the biomass surface functional groups, which are responsible for metal binding, is also being influenced [20].

4.3. Effect of Flow Rate. The effect of gas flow rate $(500,1000$, and $1500 \mathrm{~mL} / \mathrm{min}$ ) on the removal efficiency of lead in the bubble column was investigated as shown in Figure 4; it can be seen from this figure that the removal rate was highly affected by the gas flow rate. As gas flow rate increases, the removal ratio increased too. This is because increased gas flow rate causes early bubble detachment, large fluid activities (stress) at the bottom section, and bubble coalescence and (mostly) breakup [21], This leads to a large number of small 


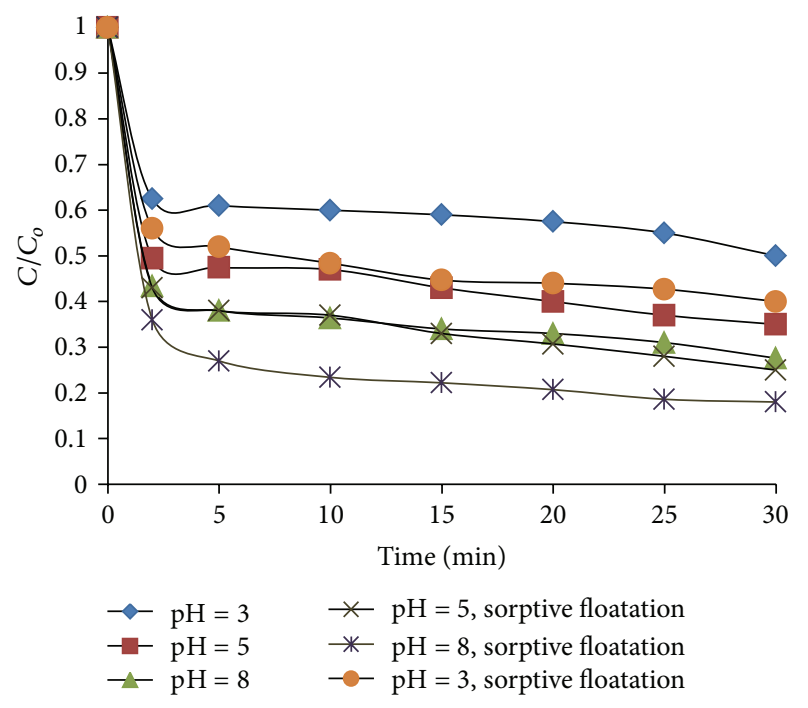

Figure 3: Effect of $\mathrm{pH}$ on the removal of lead ions $\left(C_{o}=50 \mathrm{mg} / \mathrm{L}\right.$; $\mathrm{SDS}=25 \mathrm{mg} / \mathrm{L} ; \mathrm{Q}=500 \mathrm{~mL} / \mathrm{min}$; barley husks $=20 \mathrm{gm} / \mathrm{L}$ ).

bubbles which increases surface area available for adsorption metal collector. However, higher gas flow rate results in decreasing the removal rate from the maximum due to the redispersion of some of the metal collector-precipitate product back in to the bulk solution.

4.4. Effect of Surfactant. In order to find a suitable concentration of $\mathrm{SDS}$ for removing $\mathrm{Pb}(\mathrm{II})$ ions from aqueous solutions, a series of experiment was conducted at $\mathrm{pH} 8$ in the absence and presence of barley husk using different concentrations of SDS. The results obtained are presented in Figure 5; it can be seen from this figure that the removal of $\mathrm{Pb}$ (II) increased when the concentration of SDS was $50 \mathrm{mg} / \mathrm{L}$ in the presence and absence of barley husk.

Higher concentrations of the surfactant impaired flotation, where the poor flotation at high surfactant, concentration was caused the formation of air bubbles on the surface of stable, hydrated envelope of surfactant, or, perhaps, the formation of a hydrated micelle coating on the solid surface. As a result, the hydro-PHobicity of the resulting surface was not satisfactory for flotation. These results agree with [22].

In the former case (flotation only), the $\mathrm{Pb}$ (II) may be completely adsorbed on the particle, but the husk particle could not be floated because the amount of SDS was insufficient; when the concentration increased to $100 \mathrm{gm} / \mathrm{L}$, a nearly complete flotation of husk particle could be attained [23].

4.5. Lead Concentration. The removal rate of lead at various initial lead concentrations is shown in Figure 6; from this figure, it can be seen that there is no significant difference in removal rate with increasing lead ions concentration from $50 \mathrm{mg} / \mathrm{L}$ to $100 \mathrm{mg} / \mathrm{L}$. However, at low lead ions concentration (25 mg/L), the removal rate decreased because of large surfactant: lead ion ratio which cause competition, for bubble surface, between the metal-collector product and free collector ions [24].

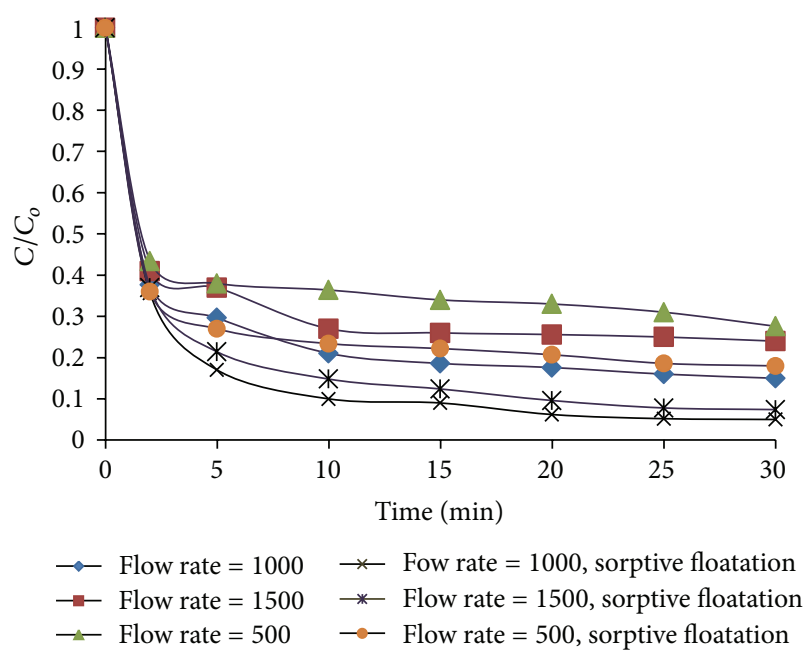

FIgURE 4: Effect of flow rate on the removal ratio of lead ions $(50=$ $100 \mathrm{mg} / \mathrm{L} ; \mathrm{SDS}=25 \mathrm{mg} / \mathrm{L}$ barely husk $=20 \mathrm{gm} / \mathrm{L}$ ).

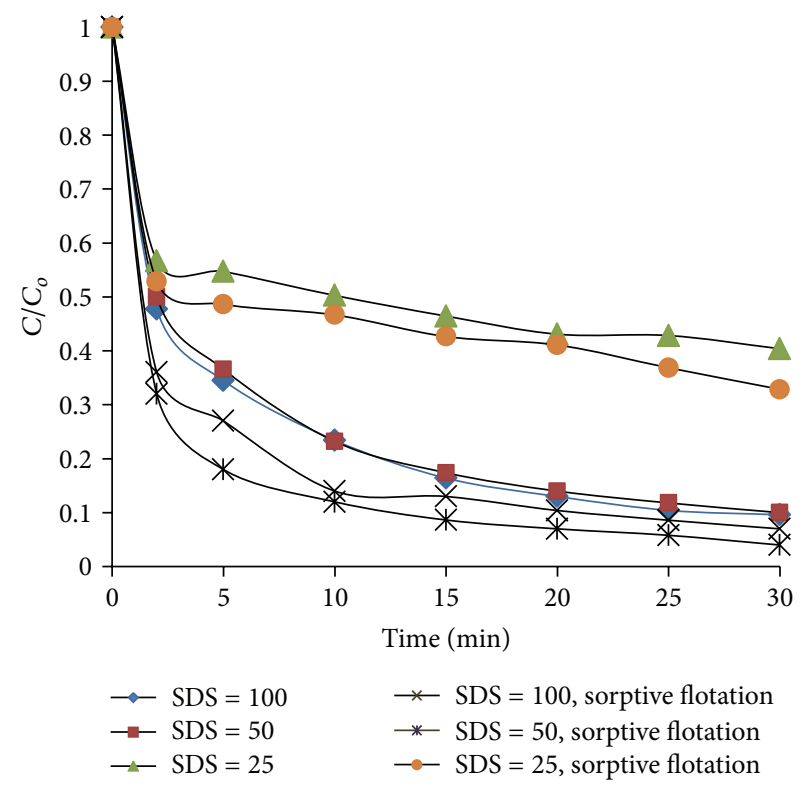

FIGURE 5: Effect of SDS surfactant on the removal ratio of lead $\left(C_{o}=\right.$ $50 \mathrm{mg} / \mathrm{L} ; \mathrm{pH}=8 ; \mathrm{Q}=1000 \mathrm{~mL} / \mathrm{min}$; barley husk = $20 \mathrm{gm} / \mathrm{L}$ ).

Also it can be seen from that figure that the removal percent increased when using sorptive flotation than flotation only.

Under the examined conditions, the separation of biomass by floatation is a very rapid process, within $3 \mathrm{~min}$. Almost $100 \%$ of biomass was separated and over $80 \%$ of lead ions removal was achieved in one stage. This is a specific advantage of the proposed sportive-flotation process, as it has been termed, because it is highly effective not only concerning lead ions removal, but also because the subsequent biomass separation process from the solution is fast and of relatively lower cost, due to necessary smaller residence time [20].

4.6. Kinetics. The amounts of barley husk used for adsorption of $\mathrm{Pb}(\mathrm{II})$ were calculated for final equilibrium-related concentration of $C_{e} / C_{o}=0.05$. The Langmuir model constants 


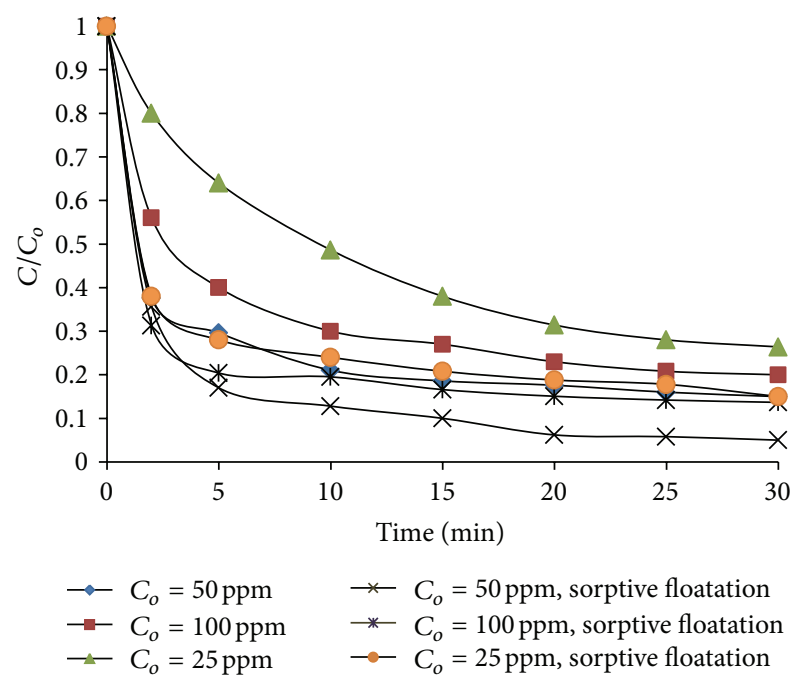

FIGURE 6: Effect of lead concentration on the removal efficiency at $\mathrm{SDS}=25 \mathrm{mg} / \mathrm{L} ; \mathrm{pH}=8 ; \mathrm{Q}=1000 \mathrm{~mL} / \mathrm{min}$; barley husk = $20 \mathrm{gm} / \mathrm{L}$ ).

TABle 2: Pseudo-first and second-order rate constants for $\mathrm{Pb}(\mathrm{II})$ with correlation coefficients $\left(R^{2}\right)$.

\begin{tabular}{ccccc}
\hline & $\begin{array}{c}\text { Pseudo-first-order kinetic } \\
\text { model }\end{array}$ & \multicolumn{2}{c}{$\begin{array}{c}\text { Pseudo-second-order } \\
\text { kinetic model }\end{array}$} \\
& $K_{1}\left(\mathrm{~min}^{-1}\right)$ & $R^{2}$ & $K_{2}(\mathrm{mg} / \mathrm{g} \cdot \mathrm{min})$ & $R^{2}$ \\
\hline $\mathrm{Pb}(\mathrm{II})$ & 0.122 & 0.936 & 1.6 & 0.506 \\
\hline
\end{tabular}

were used with the mass balance in 1.5 liter of solution. The initial concentration of lead ions was $50 \mathrm{mg} / \mathrm{L}$ with the dose of husk being $20 \mathrm{gm}$.

The rate constant using pseudo-first-order rate expression was obtained from the slope of the linear plots of $\log \left(q_{e}-q_{t}\right)$ against $t$ using (1). However, the rate constants for $\mathrm{Pb}$ (II) by using pseudo-second-order biosorption rate constant $\left(k_{2}\right)$ were determined from the slope and intercept of the plots of $1 / q$ against $1 / t$ using (2). The values of the rate constants with the corresponding correlation coefficients are presented in Table 2 for both kinetic models.

As can be seen from Table 2, the correlation coefficients for the pseudo-first-order kinetic model for the various solutes were found to be higher than that for the pseudo-secondorder kinetic. Therefore, the pseudo first-order kinetics model can be used very well to find the rate constant.

\section{Conclusions}

Investigation of the lead ions removal by floatation and sorptive-floatation methods in semibatch process using barley husk as a biosorbent was conducted.

(i) The process is highly $\mathrm{pH}$ dependent and maximum removal efficiency was obtained at $\mathrm{pH}$ value equal to 8.

(ii) The metal loaded biomass particles can be easily separated by flotation process; also the results show that removal efficiency increased with increasing air flow rate up to $1000 \mathrm{~mL} / \mathrm{min}$ for flotation and up to $1500 \mathrm{~mL} / \mathrm{min}$ for sorptive flotation.

(iii) Increasing the SDS concentration from 50 to $100 \mathrm{mg} / \mathrm{L}$ had a small effect on the removal rates which were $90 \%$ and $90.4 \%$, respectively, in flotation system while in sorptive-flotation system increasing SDS concentration from 50 to $100 \mathrm{mg} / \mathrm{L}$ leads to a decrease in the removal rate from $96 \%$ to $93 \%$ after 30 min operation.

(iv) Increasing initial lead ions concentration from 25 to $50 \mathrm{mg} / \mathrm{L}$ leads to an increase in removal rate from $73.6 \%$ to $85 \%$ while it decreased to $80 \%$ when initial lead ion concentration increased to $100 \mathrm{mg} / \mathrm{L}$ in flotation system. However, in sorptive-flotation system removal rate increased to $95 \%$ at initial lead ions concentration $50 \mathrm{mg} / \mathrm{L}$ and also decreases when increasing lead ions concentration to $100 \mathrm{mg} / \mathrm{L}$.

(v) The equilibrium isotherm data were correlated with two models; Langmuir model gave the best fit for the experimental data. The batch experiments were helpful in estimating the rate constant for $\mathrm{Pb}$ (II) by using pseudo-first- and second-order models; the results showed that the $\mathrm{Pb}(\mathrm{II})$ uptake process followed the pseudo-first-order rate model.

(vi) The results obtained in this work show that burely husk can be successfully used in removing lead ions from wastewater; also in comparison between flotation and sorptive-flotation processes, the results indicated that sorptive-flotation process is more efficient than flotation process only.

\section{References}

[1] S. E. Ghazy and A. H. Ragab, "Removal of lead ions from aqueous solution by sorptive-flotation using limestone and oleic acid," Iranian Journal of Chemistry and Chemical Engineering, vol. 26, no. 4, pp. 83-92, 2007.

[2] P. X. Sheng, Y.-P. Ting, J. P. Chen, and L. Hong, "Sorption of lead, copper, cadmium, zinc, and nickel by marine algal biomass: characterization of biosorptive capacity and investigation of mechanisms," Journal of Colloid and Interface Science, vol. 275, no. 1, pp. 131-141, 2004.

[3] Y. S. Ho, J. C. Y. Ng, and G. McKay, "Removal of lead(II) from effluents by sorption on peat using second-order kinetics," Separation Science and Technology, vol. 36, no. 2, pp. 241-261, 2001.

[4] Agency for Toxic Substances and Disease Registry (ATSDR), Toxicological Profiles, U.S. Department of Health and Human Services, Public Health Service, Atlanta, Ga, USA, 1999.

[5] V. K. Gupta and A. Rastogi, "Equilibrium and kinetic modelling of cadmium(II) biosorption by nonliving algal biomass Oedogonium sp. from aqueous phase," Journal of Hazardous Materials, vol. 153, no. 1-2, pp. 759-766, 2008.

[6] A. H. Sulaymon, S. E. Ebrahim, and M. J. Ridha, "Equilibrium, kinetic, and thermodynamic biosorption of $\mathrm{Pb}(\mathrm{II}), \mathrm{Cr}(\mathrm{III})$, and Cd(II) ions by dead anaerobic biomass from synthetic wastewater," Environmental Science and Pollution Research International, vol. 20, no. 1, pp. 175-187, 2012. 
[7] A. H. Sulaymon, A. M. Ahmed, and J. A. Tariq, "Competitive biosorption of lead, cadmium, copper and arsenic ions using algae," Environmental Science and Pollution Research, vol. 20, no. 5, pp. 3011-3023, 2013.

[8] A. H. Hawari and C. N. Mulligan, "Biosorption of lead(II), cadmium(II), copper(II) and nickel(II) by anaerobic granular biomass," Bioresource Technology, vol. 97, no. 4, pp. 692-700, 2006.

[9] G. Sun and W. Shi, "Sun flowers stalk as adsorbents for the removal of metal ions from wastewater," Industrial and Engineering Chemistry Research, vol. 37, no. 4, pp. 1324-1328, 1998.

[10] S. V. Yadla, V. Sridevi, and M. V. V. Chandana Lakshmi, "Adsorption performance of fly ash for the removal of lead," International Journal of Engineering Research \& Technology, vol. 1, no. 7, 2012.

[11] V. K. Gupta, A. Rastogi, and A. Nayak, "Biosorption of nickel onto treated alga (Oedogonium hatei): application of isotherm and kinetic models," Journal of Colloid and Interface Science, vol. 342, no. 2, pp. 533-539, 2010.

[12] J. J. Da Rosa and J. Rubio, "The FF (flocculation-flotation) process," Minerals Engineering, vol. 18, no. 7, pp. 701-707, 2005.

[13] E. Carissimi and J. Rubio, "The floes generator reactor-FGR: a new basis for flocculation and solid-liquid separation," International Journal of Mineral Processing, vol. 75, no. 3-4, pp. 237-247, 2005.

[14] J. Rubio, M. L. Souza, and R. W. Smith, "Overview of flotation as a wastewater treatment technique," Minerals Engineering, vol. 15, no. 3, pp. 139-155, 2002.

[15] L. Stoica, G. Dima, O. Micu, D. Oancea, and G. Oproiu, Heavy Metal Ions Removal By Biosorption-Flotation on Mycelial Wastes, International Mine Water Association, Granada, Spain, 2012.

[16] Y.-S. Ho, "Citation review of Lagergren kinetic rate equation on adsorption reactions," Scientometrics, vol. 59, no. 1, pp. 171-177, 2004.

[17] A. H. Sulaymon, S. E. Ebrahim, S. M. Abdullah, and T. J. AlMusawi, "Removal of lead, cadmium, and mercury ions using biosorption," Desalination and Water Treatment, vol. 24, no. 1-3, pp. 344-352, 2010.

[18] S. Sezen, S. Aibayrak, M. Imammoglu, A. Gundogdu, C. Duran, and H. Yildiz, "Dehydrated hazelnut husk carbon: a novel sorpent for removal Ni(II) ions form aqueous solution," Desalination Water Treatment, vol. 50, pp. 2-13, 2012.

[19] O. Duman and E. Ayranci, "Attachment of benzo-crown ethers onto activated carbon cloth to enhance the removal of chromium, cobalt and nickel ions from aqueous solutions by adsorption," Journal of Hazardous Materials, vol. 176, no. 1-3, pp. 231-238, 2010.

[20] M. I. Kefala, A. I. Zouboulis, and K. A. Matis, "Biosorption of cadmium ions by Actinomycetes and separation by flotation," Environmental Pollution, vol. 104, no. 2, pp. 283-293, 1999.

[21] A. H. Sulaymon and A. A. Mohammed, "Separation and hydrodynamic performance of air-kerosene-water system by bubble column," International Journal of Chemical Reactor Engineering, vol. 8, article A48, pp. 1-15, 2010.

[22] S. E. Ghazy, S. E. Samra, and S. M. El-Morsy, "Removal of copper(II) from aqueous solutions by flotation using limestone fines as the sorbent and oleic acid as the surfactant," Adsorption Science and Technology, vol. 19, no. 2, pp. 175-185, 2001.

[23] K. Koichi, S. Yoshiko, and S. Tsunetake, "The flotation of Cd2+ ions in the presence and absence of $\mathrm{Zn} 2+$ ions," Bulletin of the Chemical Society of Japan, pp. 2448-2450, 1980.
[24] K. Shakir, A. F. Elkafrawy, H. F. Ghoneimy, S. G. Elrab Beheir, and M. Refaat, "Removal of rhodamine B (a basic dye) and thoron (an acidic dye) from dilute aqueous solutions and wastewater simulants by ion flotation," Water Research, vol. 44, no. 5, pp. 1449-1461, 2010. 

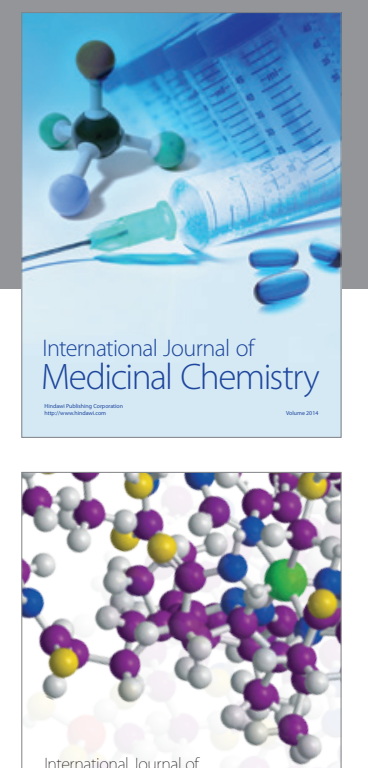

\section{Carbohydrate} Chemistry

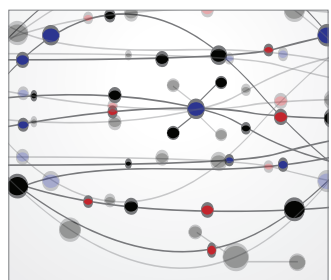

The Scientific World Journal
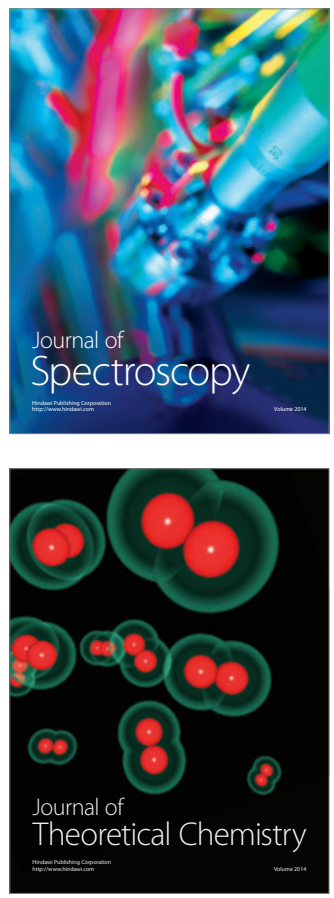
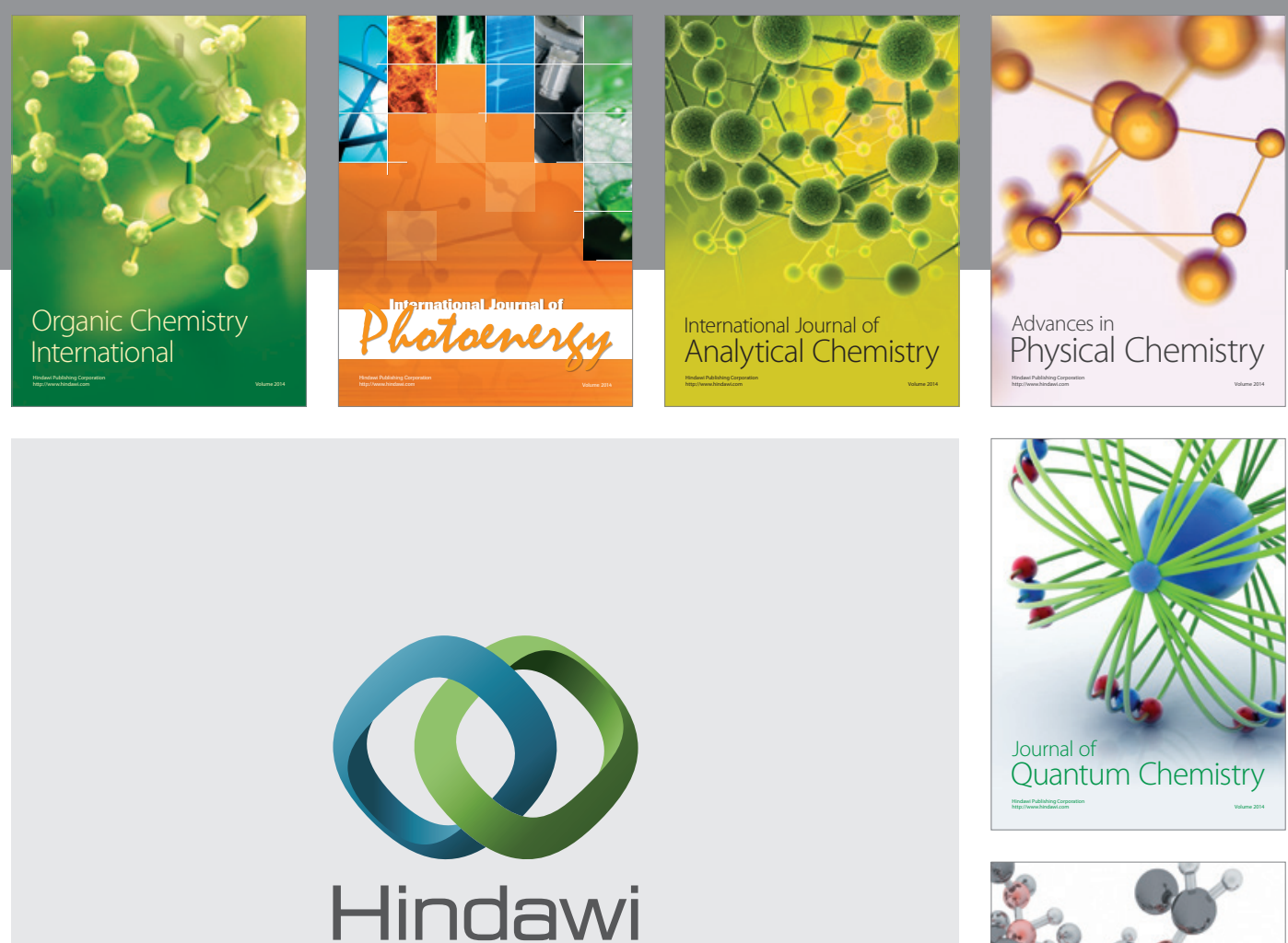

Submit your manuscripts at

http://www.hindawi.com

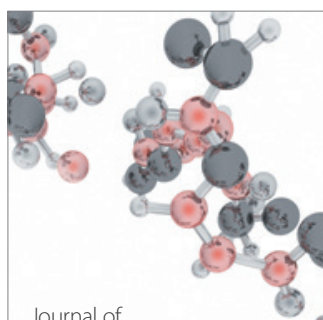

Analytical Methods

in Chemistry

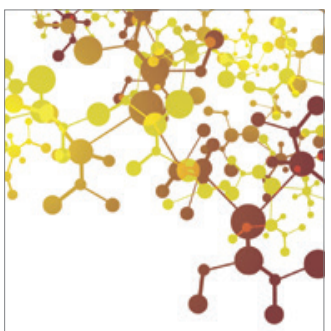

Journal of

Applied Chemistry

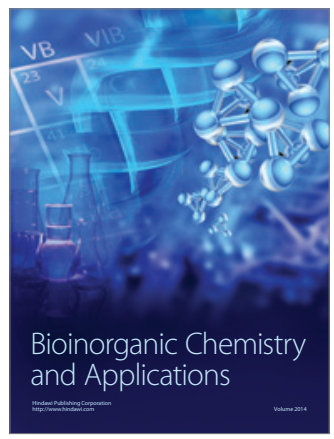

Inorganic Chemistry
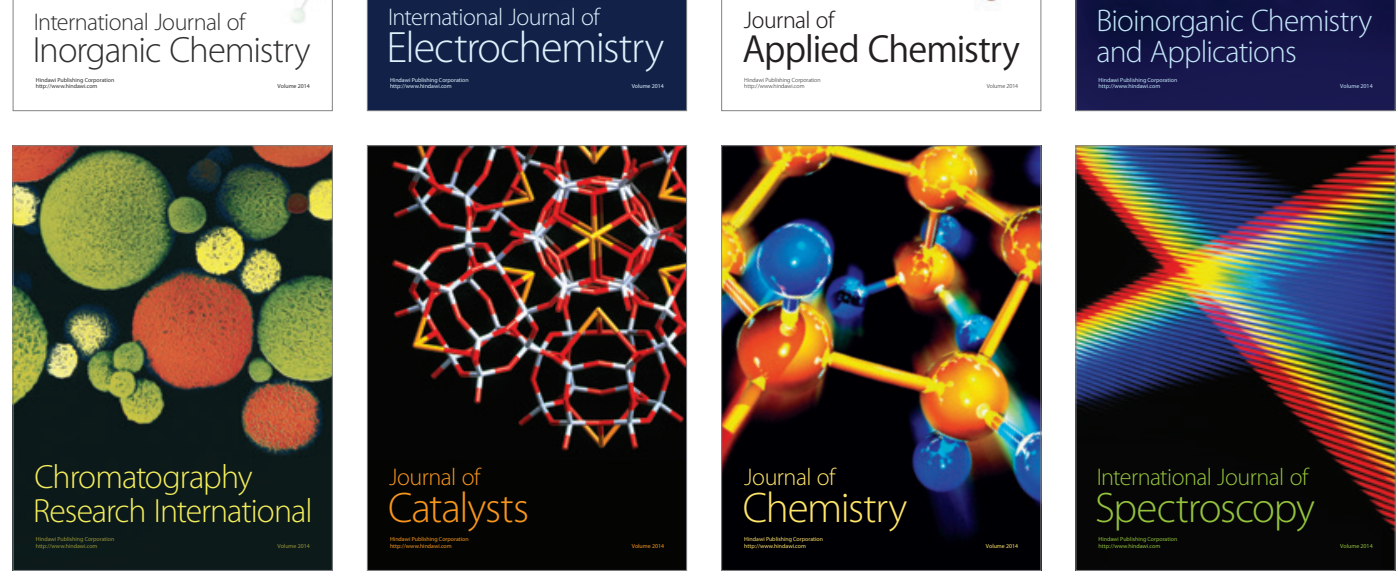